\title{
Pilgrimage and Visual Genre: The Architecture of Twentieth-Century Roman Catholic Pilgrimage in Scotland
}

\section{Robert Proctor and Ambrose Gillick}

As Roman Catholics gained confidence in twentieth-century Scotland, they revived pre-Reformation shrines and pilgrimages and created new shrines with transnational connections to the modern Catholic world. Three sites in this campaign were Carfin, a new pilgrimage center based on Lourdes; Whithorn, site of medieval pilgrimages to Saint Ninian; and Dunfermline, associated with the canonized Queen Margaret of Scotland. Each had different meanings for Scottish Catholicism. The landscapes of these shrines included proposed new buildings, completed buildings, including shrines and churches, and existing features, notably caves or grottoes and medieval ruins. Whether found, professionally designed, or made by the clergy and their congregations, these sites framed and ordered pilgrimage rituals and lent them meaning. Seeing common architectural, visual features across these pilgrimages, and drawing on new archival research, we suggest that the employment of recognizable visual genres was a key way of creating a consensus amongst the faithful. International symbols of saintly presence were remade for the local context, with intertwined religious and political intentions, giving tangible expression to a revived Catholicism in Scotland, and promoting a new vision of Scotland as a Catholic nation.

Keywords: pilgrimage; architecture; Roman Catholic; Scotland; modern; twentieth century; landscape; history

\section{Introduction}

Twentieth-century Roman Catholic pilgrimage in Scotland arose through the making of a broad consensus across laity and clergy, in which particular genres of visual, material and spatial form were considered capable of bringing the spiritual world into closer contact with the nation. Natural, historical, and newly constructed spaces of pilgrimage were shaped and ritually interpreted to this end. In each, clergy and laity acting together localized the sacred through the deliberate crafting and activating of buildings, images, and places. This 
pilgrimage work settled around visual genres, material forms following an expected pattern that inculcated certain ways of viewing and acting in relation to them. Reconfiguring the nation's geography according to these agreed forms aimed to allow the sacred to recolonize the landscape, to remake Scotland as a country in which Roman Catholic Christianity was visibly emergent, and ultimately as a Catholic nation.

The three most notable Catholic pilgrimages in twentieth-century Scotland fall into two categories, but share many features. At Dunfermline, burial place of St Margaret, medieval Queen of Scotland, and at Whithorn in Galloway, associated with the fifth-century St Ninian, pre-Reformation pilgrimages were revived (on the latter, see Proctor, 2014, 252254); yet given the post-Reformation loss of relics and buildings these new pilgrimages and their material surroundings took modern forms. These revivals heightened a sense of separation from the past, emphasizing the dearth of "authentic" Catholic material culture in the landscape - a void creatively filled by drawing on normative spatial and visual genres of modern Catholic pilgrimage. The ruined medieval shrines of Dunfermline Abbey and St Ninian's Priory were unavailable to Catholics for worship, and pilgrims focused instead on natural caves with legendary associations; on open-air ceremony; and on the construction of new buildings evoking a longed-for revival. Meanwhile at Carfin, near Motherwell, a pilgrimage garden of shrines was cultivated, forging a completely new landscape to accommodate the saints of the universal church. Here, caves were not found but made, open-air ceremonial was framed, and buildings were planned and produced.

These activities in Scotland were part of a growing movement in Britain in the late nineteenth and early twentieth century, as an increasingly emancipated and culturally powerful Catholicism publicly addressed concerns of identity and authority. Giles Mercer argues that the Glastonbury pilgrimage of 1895 'pushed the boundaries' of Catholic worship in public spaces in Britain. In the context of Catholic and Anglican rivalry over continuity, 
this event demonstrated Roman Catholics' claims to be the inheritors of medieval Christianity (Mercer, 2012). There are parallels too with the revival of the medieval pilgrimage of Walsingham, begun by Catholics in the late 1890s and popularized in the 1930s in response to an Anglican shrine. Simon Coleman shows how experience of the surrounding landscape supported a narrative of English identity for Catholics (Coleman, 2004, 60; see also Coleman, 2009). Mercer and Marion Bowman also explore the modernity of this pilgrimage revival, stimulated as it was by the railway, increased leisure time, mass migration into British industrial centres from Ireland, and the growing influence of the Catholic Truth Society in disseminating accessible Catholic narratives of history and the saints (particularly the English Reformation Martyrs) through popular books and pamphlets (Mercer, 2012; Bowman, 2015).

Scotland in the twentieth century shows a dissemination of this pilgrimage culture, but also a development beyond it, as the forms and meanings of pilgrimages proliferated in this new context. One distinctive and important feature of the Glastonbury pilgrimage was the role of the clergy in encouraging the laity's response, a characteristic also of Scottish Catholic pilgrimages. Examining the mechanisms of clergy activity can develop our understanding of pilgrimage shrine creation, reconsidering recent and classic theories of pilgrimage, drawing especially on Leonard Primiano's concept of 'vernacular religion'. We prioritise, however, an art history, architectural history, or cultural history approach informed by David Morgan (2005), rather than ethnography. Historical sources such as correspondence, drawings, photographs, newspaper articles, and other publications of the period, including those at shrine archives and the Scottish Catholic Archives, enable a rich picture of shrine construction, development and use and the motivations behind them.

Before exploring theoretical arguments, we begin by surveying the three pilgrimages, Dunfermline, Whithorn and Carfin. The Roman Catholic pilgrimage and parish church at 
Dunfermline, St Margaret's Memorial Church (fig. 1, 2), was designed by Robert Rowand Anderson around 1892 and opened when partly completed in 1896 (Maguire, 1936, 52, 60-62; Catholic Directory, 1946, 16; drawings of 1894 at UEA, Coll-31/2/EC/146a; “(Sir) Robert Rowand Anderson," n.d.). Its Romanesque style is unusual in Anderson's work, and precedes the fashionable use of that style in the early twentieth century. It may be understood as a response to its place and dedication: a church of a type that might have been built in the 11th century when the saintly queen reigned, and echoing the style of the medieval Abbey nave. The parish priest George Mullan promoted devotion to St Margaret throughout Scotland and beyond, raising funds for a building beyond the capability of the small parish. He organized a pilgrimage by train from Edinburgh in June 1899, but was then transferred to another parish. In 1930, the Catholic Truth Society instituted an annual pilgrimage described as 'national' with the approval of Archbishop Andrew McDonald, continuing until the war and revived again in 1951 (Maguire, 1936, 65, 68; letter from James Black of 31 January 1951, SCA, DM/55/1; Catholic Directory, 1946, 20, 23). Following the church's rapidly developing pilgrimage function, Reginald Fairlie was commissioned to extend it eastwards with a new sanctuary in 1938; a reredos with sculpture by Hew Lorimer completed the scheme in 1940, depicting Scottish saints, Andrew, Columba, Mungo and Margaret, following the style of Anderson's nave (fig. 3) (Catholic Directory, 27; SCA, GD/70/13). Yet the church was not the main focus of the pilgrimage, since it was too small for the tens of thousands attending this event after the war, and instead Mass was said in the local football stadium.

Pilgrimages at Whithorn similarly began in earnest in the 1930s and continued after the war with annual exhortations from the Bishop of Galloway, Joseph McGee, who made its diocesan and national development his personal cause (pastoral letters, 17 July 1953, 12 July 1954, 20 July 1955, 15 October 1956: SCA, DG/6/13). The little tin church of the 1890s was 
the parish's only building, and the pilgrimage gathered instead at the seafront cave a few miles away reputed to have been St Ninian's chapel of retreat. Mass was celebrated on the beach in an often intemperate Scottish September. By 1951 a prominent site for a new church was found on George Street, Whithorn's main road, close to the ruined medieval Priory where St Ninian was thought still to be buried. That year Basil Spence designed a new modern church (fig. 4) (designs of 1951: SCA, DG/74/174/1; correspondence on acquisition of a site, 1945-1950: SCA, DG/73/160, DG/73/161). But, disliking the design, McGee turned instead to H. S. Goodhart-Rendel, who designed a neo-Gothic church in 1955, much reduced in execution in 1959-60 by his assistant H. Lewis Curtis (fig. 5) (design drawings, 1955: SCA, DG/73/173/2; drawings, 1959: SCA, DG/73/174/3; correspondence between Goodhart-Rendel, Curtis and McGee: SCA, DG/73/174/4, DG/54/3, DG/54/5-7). With limited funds, the church remained too small for the pilgrimage, but its site allowed open space and an outdoor altar for Mass, the open-air ceremony remaining a desirable feature. The modest, almost vernacular church that was built suggests a shared lay and clerical desire to promote ideas of Catholic indigeneity.

In contrast to Dunfermline and Whithorn's appropriation of localized saints, Carfin, a site dedicated to Our Lady of Lourdes, emerged from the parish priest Thomas Nimmo Taylor's enthusiasm for French pilgrimages and an international culture of popular devotions (Harris, 2015). Taylor acquired this enthusiasm during his training at the SaintSulpice seminary in Paris. Appointed to the parish of St Francis Xavier, Carfin, in 1915, he organized a parish pilgrimage to Lourdes in 1922 and on returning inspired his parishioners to build a replica Lourdes grotto on land opposite the church (Taylor, 1938, 4). Mains water was diverted into a rivulet mimicking St Bernadette's miraculous spring, a faucet enabling visitors to fill containers, as at Lourdes. The grotto was rebuilt twice (fig. 6), and the site developed an extraordinary array of shrines. The next most important was the shrine of St 
Thérèse of Lisieux, perched on a purpose-built rockery overlooking the grotto: an initial version of 1921 was rebuilt at larger scale in 1931 and 1935 (fig. 7) (Taylor, 1938, 10-11, 29; [Taylor], 1933). Taylor helped advance her cause for canonization, achieved in 1925; he translated her autobiography for the Catholic Truth Society; and befriended her convent sisters, who gave him several relics. Unusually for a British pilgrimage shrine at this period, devotion at Carfin was ascribed miraculous powers. Events attracted huge crowds from across Scotland and England (up to twenty times those attending the first Glastonbury pilgrimage), principally on feasts of the Virgin and St Thérèse (fig. 8). Lourdes provided the ritual model: Benediction was given from a ledge over the grotto, and candlelit processions took place at dusk. The shrine's wide shelving spaces accommodated crowds assembling and processing in intricately planned ceremonies.

Further shrines included a water garden with an island of Our Lady of the Sea; a Bethlehem cave; a mound dedicated to St Anthony of Padua and St Francis of Assisi, with associated Portiuncula chapel; a "Calvary;" and a giant statue and altar of Christ the King, all added in the 1920s. After the war a diminutive "Nazareth" was built: an excavated walled courtyard depicting the sorrows of Mary on its walls leading to the domed "Santa Casa" of the Holy Family (fig. 9) (Taylor, 1938, 20-21, 24-25; Taylor, n.d. [c. 1950], 3). A "Lourdes Institute" (a hall giving food and shelter to pilgrims) was built against the grotto, and a timber "Chapel of All Saints" housed Taylor's enormous collection of relics. Reginald Fairlie designed the shrine's gateway, and was invited in 1924 to design Taylor's dream church, an enormous project described by Taylor as a "votive church" of "Our Lady of Lourdes and St Thérèse," seating six thousand inside and twenty-five thousand pilgrims in a forecourt (Taylor, 1938, 12; Nuttgens, 1959, 30-31, and plates 27-28). Taylor acquired the site and maintained the dream until his death in 1963, when it was abandoned. Fairlie's former 
pupil Charles W. Gray later designed a small modern church overlooking the shrine with a striking circular design, completed in 1973 (Solemn Opening, 1973).

\section{Clergy and Laity}

These three pilgrimages strikingly contradict a tenet of Victor and Edith Turner's classic anthropological theory of Christian pilgrimage (Turner and Turner, [1978] 2011, e.g. 31-32). According to this theory, pilgrimage begins with a popular lay response to a rumored miraculous happening - an apparition, a cure, a found or moving statue - a response overflowing with fervent emotion and spontaneously emerging rituals. Later, Church authorities intervene to impose orthodox doctrine and channel popular enthusiasm into acceptable forms. Spaces, buildings and imagery become tools to constrain pilgrimage activities and beliefs into doctrinally acceptable forms. Recent anthropological scholarship on pilgrimage has questioned the Turners' ideas, emphasizing the heterogeneity of pilgrimage practices, and exploring tensions and conflicts within them, particularly ways in which the laity exceed or defy the limits desired by the clergy (Eade and Sallnow, 1991; Mesaritou 2012 and 2015; Turner, 2009). From a historical standpoint, reliant on documentary evidence generated by institutions rather than ethnography, such conflicts are often now invisible. Focusing on the clergy's role in producing pilgrimages suggests instead that their construction of specific visual forms enabled a broad popular consensus. Rather than reasserting the Turners' emotive or social (Durkheimian) concept of communitas, this analysis shows how popular pilgrimage could be deliberately generated through material culture.

As at Glastonbury, all the Scottish pilgrimages were initiated by clergy: George Mullan, later Vicar-General of the Archdiocese of St Andrews and Edinburgh, sought out 
sponsors, placed advertisements in the Catholic Directory advocating devotion to St Margaret alongside appeals for funds for her "national memorial church", and printed photographs of Dunfermline Abbey and her statue for distribution (Maguire, 1936, 52 and 57). The Archbishops of St Andrews and Edinburgh endorsed the Dunfermline pilgrimage: William Smith first inspired the campaign (St. Margaret's, 1946); Angus MacDonald wrote blessing the enterprise in 1893 (Maguire, 1936, 56); Andrew Joseph in the 1930s sent pastoral letters urging parish priests throughout Scotland to promote the pilgrimage to the laity and to bring them in great numbers (e.g. letter to clergy, 25 June 1931, SCA, DE/32/3). At Carfin, popular enthusiasm may have appeared most spontaneous, but was carefully orchestrated and narrated by Taylor. The Bishop of Galloway, Joseph McGee, was the prime mover in the cause of St Ninian, exhorting the faithful to pilgrimage; in a letter to clergy of 3 February 1956 he asked every parish in the diocese to help fund the building at Whithorn, and oversaw its design himself (SCA, DG/54/3).

At this institutional level, however, there were notable tensions. Whithorn's parish priest, Cornelius Burke, wrote to the bishop of his 'very great shock' at the building's cost (14 January 1963, SCA, DG/54/109), suggesting a disparity between the parish's tiny population of Catholics and the size of the builder's invoices for this prestigious project. The Archbishop of Glasgow, Donald Mackintosh, wavered between endorsement and criticism of Taylor's work at Carfin. Mackintosh reproached Taylor for occasional transgressions of his authority as a parish priest. He upbraided him for an evasive financial report and commitment to expenditure and debt beyond the levels that the diocese permitted other parishes, and when Taylor campaigned for funds for Fairlie's church without having it approved by the diocesan Finance Board as expected for all parish building work (annual financial statement for St Francis Xavier, Carfin, 1926, with notes by Mackintosh, ARCAG, MW/11/1/15; letter from Mackintosh to Taylor, 14 March 1942, ARCAG, GC/74/3/1). 
Mackintosh complained most strongly about what he considered excessive statements made at Carfin without diocesan approval by Cardinal Bourne of Westminster on a ceremonial visit to dedicate an altar in 1924 (fig. 10). Mackintosh's rebuke (Mackintosh to Taylor, 30 July 1924; Taylor to Mackintosh, 25 August 1924: SFX) concerned claims that Bourne had acknowledged miraculous cures at Carfin, whereas only diocesan authorities could declare the authenticity of a miracle. These criticisms point to tensions over territory, hierarchy and religious priorities: Burke and Mackintosh emphasised the universal norm of the parish and diocesan structure, its financial duties, and implicitly perhaps therefore its liturgical routine, over the specificity, mobility, and devotional aspects of pilgrimages.

Mackintosh's complaint about Bourne was partly territorial, since the cardinal had no jurisdiction beyond England and Wales. At the shrine, preaching to a crowd estimated at between thirty and fifty thousand, Bourne alluded to the alleged miracles, and praised the pilgrims' devotional fervor. "He could not tell them why Carfin had been chosen to be such a centre of devotion," reported the Tablet ("Cardinal Bourne in Scotland," 1924). "It was God's doing, and it was His choice. [...] The gathering of so many thousands in the grotto there for devotional exercises was, he said, a magnificent and consoling sight." Yet Mackintosh had previously encouraged Taylor's ambitious acquisition of land for the grotto, and he and other Scottish bishops often led pilgrimage events at Carfin - Mackintosh blessed the statue of Thérèse in 1924, and his successor Archbishop Donald Campbell presided over ceremonies for the fiftieth anniversary of the saint's death in 1947 (Mackintosh to Taylor, 7 September 1923 and Mackintosh to Taylor, 19 March 1924: SFX; “Little Flower," 1947). At all three sites, notable Scottish clergy and religious led processions. Archbishop Gray was a particularly assiduous advocate of pilgrimages, leading diocesan tours to Lourdes and Rome and preaching at Carfin and Whithorn, besides cultivating the Dunfermline pilgrimage in his own diocese (recorded in his sermons: SCA, DE/161/70, 1-8). 
Any popular enthusiasm evident in Scottish pilgrimages therefore resonated with the clergy's own devotional fervor. The evidence suggests little if any distinction between the beliefs of the institutional hierarchy and those of the laity, at least from this historical vantage point.

Rather, the evidence might be explained by considering the arguments of Primiano (1995 and 2012) for adopting a concept of "vernacular religion." Observing the inherent complexities of religious practice, Primiano asserts that "What scholars have referred to as 'official' religion does not, in fact, exist" (Primiano, 1995, 45). Instead, he questions such binary opposites as clergy versus laity, official versus folk, in which popular beliefs are seen as subversive resistance to institutional dogma. Rather, Primiano advocates studying religion as it is experienced and lived, whether by laity or clergy, seeing even institutional texts and actions as products of the lived religious beliefs of individuals, situated in particular times and places, in relation also to wider (secular) cultures (e.g. Primiano, 1995, 42). This theory resonates with the evidence for these case studies: the material manifestations of the sites of pilgrimage at Carfin, Dunfermline and Whithorn are constructed within a specific context by earnest believers, clergy and laity, grounded within the cultures of early twentieth-century Scotland and modern Catholicism.

Lay participation in these pilgrimages was not confined to a popular, devotional "folk" response, but also included "elite" contributions to their formation and development - most notably from the Marquesses of Bute, prominent and wealthy aristocratic Catholics. The Third Marquess seems to have initiated the idea of building a church to St Margaret at Dunfermline, perhaps because the Butes claimed descent from the queen. The Marquess chose Anderson as the architect and at various points oversaw the design. He considered funding the porch and baptistery as a subsequent phase of the building (although his death intervened), and he and his wife contributed fifteen hundred pounds to the building fund 
(financial documents of 1894, SCA, DE/39/2 and 1903, SCA, ED/18/18/15). The largest lay donors here were the Smith Sligo family, prominent Catholics and patrons, who bought the site as well as contributing to the building (SCA, ED/18/18/15; Maguire, 1936, 52). The Third Marquess of Bute was also interested in Whithorn, sponsoring archaeological excavations at the Priory and acquiring land for the parish in the 1890s, stimulating the production of authentic historic artefacts around which new cultic practices could develop (Roberts, n.d., 7). His grandson, David Stuart, became involved in the post-war building project: he seems to have commissioned Spence's design himself, acting as intermediary between Spence and the diocese; he offered to make a "National appeal for a National Shrine of St Ninian," elicited funds from a family trust, and made his own donation (David Stuart to [William Mellon] (Bishop of Galloway), 27 September 1951; D. McCarthy to [Mellon], 22 October 1951; McCarthy to [Mellon], 10 February 1954; David Stuart to [Mellon], 1 September 1954: SCA, DG/54/2; Walker \& Sharpe to Cornelius Burke, 21 November 1960, SCA, DG/54/10).

What seems evident in these shrines is a shared belief in the efficacy of certain visual and spatial forms or genres. If conflicting beliefs and practices did exist, the use of agreed forms adhering to genre could elide or even resolve those tensions, much as a ritual practice can unite its practitioners with a single "ritual commitment" while enabling multiple interpretations to coexist (Humphrey and Laidlaw, 1994, e.g. 5). This consensus allowed initiatives that conformed to expected conventions to gain endorsement and response at all levels, as Taylor inspired his parishioners to create Carfin's series of shrines and attracted vast pilgrimage crowds while largely achieving acceptance from the Church hierarchy. Consistent visual forms, found or created at a site, became efficacious in opening up spaces for the inhabitation of the sacred. At these points the saints became present and accessible in special ways, rehoused within the Scottish landscape and made available for intercession on behalf of individuals and the nation. These formal genres inspired pilgrimage because they 
were known and agreed to belong to that form of Catholic devotion, in which specific devotional activities took on heightened meanings in certain places; and they also arose from the specific context of twentieth-century Catholics in Scotland in which these beliefs were enacted.

\section{Visual Genres of Pilgrimage}

One architectural historical mode of analysis considers how building typologies, shared visual and spatial forms, can be identified and their intended meanings sought, and can contribute to an understanding of these sites. Applied to the visual culture of religion, this approach is also taken by David Morgan. He argues that modes of behavior in relation to images are elicited by cultural expectations associated with their adherence to rules of genre, and itemizes the different ways in which social consensus about the uses of images arises. “The rules, implicit in a given genre of imagery and the occasion on which an image is viewed, stipulate conditions such as [...] what the viewer can expect from the act of seeing," he explains in The Sacred Gaze (Morgan, 2005, 3-4): "Protocols also urge appropriate demeanor, gesture, and response among viewers." Bowman and Valk $(2012,8-9)$ note similarly the prevalence of genre in popular religious beliefs, applied by essays in their collection to shrine making and tales of miracles (Panchenko, 2012; Pócs, 2012).

Persistent visual, architectural and related narrative and devotional genres can therefore be identified in these three pilgrimage sites; their meanings and the sources of their efficacy can be analyzed. Some elements may be particular to British Catholicism (not just to that of Scotland); some also adhere to an international Roman Catholic visual language. Similar religious visual imagery proliferated, particularly from the late nineteenth-century onwards, in devotional literature, religious newspapers and magazines, generating 
“imagined communities" (Anderson, 1991) of Roman Catholics sharing a visual and cultural language. Other sources may include travel; catalogues of statues and devotional objects used by parish churches and the faithful; and institutional processes of defining fixed forms for orthodox imagery, such as those established by the Council of Trent. There are also resonances with aspects of secular culture in twentieth-century Scotland, as this was a period of increasingly strong national consciousness and identity, indeed of growing nationalism.

\section{Connecting to a Lost Catholic Past}

Firstly, there is a persistent interest in medieval ruins, and in the associated view of the Gothic as a national Catholic restoration, a well-understood aspect of Victorian Catholic church architecture with special resonances at pilgrimage sites. All but a few medieval sites in Britain were outside Catholic ownership, and often inaccessible for religious purposes, providing a poignant backdrop to pilgrimages at Dunfermline and Whithorn, as at Glastonbury and Walsingham (Mercer, 2012; Coleman, 2009, 24-25). British Catholic culture often dwelt on its lost inheritance, evoking the religious geography of medieval Catholic Britain, articulating a sense of alienation from the nation felt by often immigrant, poor and marginalized congregations. The Catholic past was irretrievable, marked as it was by the Reformation's caesura, sustained in Catholic culture through the cult of the Reformation martyrs. The Victorian hymn "Faith of Our Fathers" encapsulated this notion, defining physical sacrifice as necessary to return the nation to Catholicism. This hymn was a favorite at two of the pilgrimage sites - sung at the ruins of St Margaret's tomb at the first pilgrimage to Dunfermline in 1899 and in procession during the Catholic Young Men's Society pilgrimage to Whithorn in 1936, for example (SCA, GD/40/1; CYMS, 1936, 8, 14). In Scotland, 
as in England, devotion to pre-Reformation saints was encouraged by the hierarchy, concerned to emphasise Catholic continuity over the Irish immigration and identity that predominantly characterized British Catholicism (e.g. McCaffrey, 1978, 144); though "native" Gaelic Christianity was largely downplayed in favor of saints whose hagiographies expressed the ordering influence of Rome on Scotland (Burnett, 1998).

At Dunfermline, the pilgrimage could not use the twelfth-century Abbey nave. It was in the possession of the state, maintained as a historic monument along with the ruined Abbey and royal palace, while on the site of the choir was an early nineteenth-century Church of Scotland (Protestant) church. The first pilgrimage Mass in 1899 took place at a small convent chapel overlooking the Abbey grounds, but in its mid-twentieth-century form the pilgrimage gathering occurred first in and around the Catholic church (fig. 11), and then, as attendance grew to the tens of thousands, at the town's football stadium (Archbishop Andrew Joseph, letter to clergy, 25 June 1931, SCA, DE/32/3; “Annual Pilgrimage,” 1961; souvenir calendar of St Margaret of Scotland Guild, 1950, SCA, GD/70/61). Every pilgrimage included a procession to the remains of the medieval shrine of St Margaret, a mere stone platform surrounded by railings, located behind the Church of Scotland building (fig. 12). The medieval site was thus the focus of the pilgrimage, but defined by the absence of the saint and the exclusion of the Catholic faithful. A relic of St Margaret, acquired at the Escorial in Spain in the mid-nineteenth century by Bishop James Gillis, was kept in a Gothic revival reliquary at the convent of St Margaret in Edinburgh, and was taken from Edinburgh to Dunfermline to be carried in the procession in a symbolic revisiting of the saint to the shrine from which she and the faithful were exiled.

The site for Anderson's church was described in parish literature as a former possession of the Abbey, symbolically connecting it to the medieval Catholic past (St Margaret's, Dunfermline, 1946, 11). The design of the church is, however, illogical: its style of 
Romanesque is later than that of the surviving Abbey nave, perhaps so as not to attempt to rival it, implying a church that medieval builders might have constructed in St Margaret's honor; though she was not declared a saint until the thirteenth century. The round tower that Anderson proposed implies an earlier Celtic presence (fig. 13). Perhaps, if there was any reasoning beyond picturesque associations, the building evoked the merging of Celtic and Roman Christianity attributed to Margaret's reform of Scottish religion, much discussed in later Catholic publications (e.g. Kerr, 1930, 20-23; “Dunfermline Pilgrimage,” 1953) emphasizing, therefore, the Roman Catholicism of Scottish medieval Christianity. Fairlie and Lorimer's sanctuary repeated the combined associations - Romanesque arches and statues hinted at Celtic design, while polychrome marble floors and walls were markedly Italianate.

At Whithorn, literature and sermons on St Ninian described him as a missionary sent from Rome to introduce Roman rule to his fellow Celtic Christians, and this may have been why his cult was favored by Scottish Catholics to the relative neglect of St Columba. The legend of Ninian's diversion to visit St Martin (included in the parish's dedication), and of his transportation of white stone and a style of building from St Martin's abbey at Marmoutier to create the "Candida Casa" at Whithorn, said to lie under the ruined priory's foundations, reinforced the international associations of the pre-Reformation Church in Scotland. This emphasis Burnett sees as imposed by the clergy and Catholic historians via the Catholic Truth Society on Scottish Catholicism (1998, 179-180), and was perhaps meant to counter the widespread appropriation of Ninian and many Celtic saints as representatives of a primitive Protestant Christianity in many Church of Scotland church dedications (McKerlie, 1936, 3-7). When Archbishop Gray of St Andrews and Edinburgh preached at the pilgrimage in 1954 (sermon at SCA, DE/161/70, 8), he emphasized the continuity of contemporary Roman Catholicism with Ninian's Christianity: 
What is important to us is this - that Ninian who first brought the pure unadulterated teaching of Christ to our shores, who is recognised by all today as having done so, went to Rome for the Truth and came back to teach it with the authority and at the command of the then reigning Pope. What is important to us is that he brought with him the same Mass at which we assist today, outlawed indeed at the Reformation, yet midst danger and peril, in secret hiding, offered continually throughout the penal days until our own time. [...] Strathclyde in the fourth and fifth centuries was in many respects not unlike this same territory today. It had then as today the Truth but for the most part incomplete. Ninian gave it the whole Truth.

The conversion of Scotland to Catholicism was explicitly articulated as a return to a preReformation state: "Let this country know that your Faith is not something foreign," Gray continued. "It is the Faith of Ninian in the fourth century. [...] Of Robert the Bruce who bore Our Lady's image on his sword and came here on pilgrimage" (SCA, DE/161/70, 8). As at Dunfermline and Glastonbury, the medieval priory ruins could be visited but not used for worship, and were listed on pilgrimage itineraries as an optional activity separate from the ceremonies. The Catholic consciousness of a fractured nation was therefore heightened through the presence of the unusable ruins lacking any sign of the historic shrine and its treasury of royal pilgrimage gifts described in histories of the site.

The pilgrimage gathered at first at the seafront cave reputed to have been Ninian's first chapel, and then in 1960 at the new parish church of Saints Martin and Ninian. Goodhart-Rendel's first design for this building in 1955 was approximately early Gothic in style (drawing of 23 November 1955 at SCA, DG/73/173/2), unadorned for economy but imposing (fig. 14), to the extent that the local authority's planning advisor Richard E. Moira criticized it as 'absolutely out of scale' with the street (letter to county architect, R. M. Clive, undated [1957], SCA, DG/54/5/12). As far as Goodhart-Rendel could achieve on the modest 
budget, it was a landmark asserting a Catholic presence in the town, though medieval more in approach than style: "I have wanted to make the church a monument simple and grave," he wrote to McGee (21 December 1955, SCA, DG/54/2), "with only such stylism about it as comes naturally when building with solid materials," including granite, "and avoiding all delicate labours." He also suggested an affinity with seventeenth and eighteenth century Scottish churches, then favored by architect Ian Lindsay and Catholic historian Peter Anson, involved with the Catholic church of St Finnan, Invergarry in that style (Watters, 2016, 23-24; Ross, 1978, 46-47). As in Anderson's design, there was more romanticism than reason about Goodhart-Rendel's church for Whithorn, unless it was meant to suggest what might have been built as the town's parish church had the Reformation never happened, as the architect hinted (letter to County Clerk, 8 August 1957, SCA, DG/54/5/15). Greatly simplified in execution, however, the completed building looked less Gothic and more domestic (closer to Lindsay's approach) - a counterpoint to the vanished marvels of the priory, which can only have heightened the sense of loss of the nation's Catholic past - all the more so as the pilgrimage gathered outdoors around the altar built outside the rear wall of the sanctuary. Carfin had no ruins, but it did have Gothic dreams: Fairlie's giant votive church design adopted the architect's favored Scottish Gothic (fig. 15). Its proposed dedication to the modern devotions of Our Lady of Lourdes and St Thérèse of Lisieux hardly relate to the historic style, except for the fact that Lourdes had a similar dream church in romantic Gothic, the nineteenth-century Basilica of the Immaculate Conception built over the grotto by Hippolyte Durand. The designs are different (Lourdes is light and vertical, Carfin squat and square), but if one also considers the lower and later Rosary Basilica at Lourdes of around 1900, the assemblage of spaces in both is similar. Fairlie's broad forecourt is Romanesque (fig. 16), resembling the esplanade arches at Lourdes. His tall entrance arch was evidently intended for outdoor ceremonies such as Benediction overlooking the crowds, 
like a unified and heightened version of the centrally-arched facades of the superimposed Lourdes churches (and similar to that at the Basilica at Lisieux, designed a year or two later (Basciano, 2018)). The medieval Scottish style was relevant to Carfin, as Taylor frequently asserted parallels with pre-Reformation practice. His collection of relics and their use during ceremonies was, he wrote, "an aspect of the Grotto's work which is of immense interest because it restores to Scotland a form of devotion which has been forgotten among Catholics in Scotland since the fury of the Reformation" ([Taylor], 1962, 28); and he often asserted that Carfin's devotions aimed to convert Scotland to Catholicism ([Taylor], 1947). Indeed dramatic conversions of Protestants were a much-publicized feature of the shrine.

All three sites therefore co-opted the medieval, present in the ruins and revived in medieval styles, as a mechanism for reviving the lost Roman Catholic faith of the Scottish people. Glastonbury again provides an interesting parallel: Mercer interprets the use of the Victorian Benedictine Abbey Church at Downside for the pilgrimage starting point as a demonstration of how Glastonbury's ruined Abbey had been recreated by modern English Catholics (Mercer, 2012, 98); and these three Scottish sites demonstrate a similar mentality. Through ritual action, including processional movement around or past the medieval fragment, the acknowledgement of the presence of saints restored them to the contemporary world as participants in the lives of the pilgrims and the Church. The work of imagining, commissioning, designing and raising funds for ambitious churches promoted the restoration of Catholicism to Scotland through forms expressing continuity with the medieval world. The huge numbers that came on pilgrimages to the shrines provided proof of the efficacy of these sites in bringing about this Catholic restoration, and the ambitious scale of the church designs, all beyond their parishes' means, addressed a national audience and envisaged an optimistic future for Scottish Catholicism. 


\section{The Sacred in the Scottish Landscape}

Another visual and spatial genre common to all three sites is the cave or grotto. The cave is evocative of Celtic folklore, of the Romantic landscape of Ossian's tales, besides those of more classical European myths. Modern pilgrimage borrowed this genre form from sites of tourist travel, notably Fingal's Cave (and the natural wonder of the cave and its heroic or oracular associations has a similar romantic and picturesque origin to the taste for ruins). Yet if these allusions were present in the Catholic imagination, they were not articulated as such. At Whithorn (far from the Western Isles) it was simply the legend that St Ninian had used the cave as a private chapel that attracted the pilgrims; crosses carved on its walls were thought to be medieval, confirming the presence of earlier pilgrims (Roberts, n.d., 5; letter of McGee to clergy, 20 July 1955, SCA, DG/6/13/11). At Dunfermline, a cave was reputed to have been St Margaret's place of retreat and private prayer. Though the interior was inaccessible to the pilgrim crowds, its overgrown entrance in the side of the river bank was a focal point for devotion. The town council proposed in 1961 to build a car park that, by flattening the topography, would bury this entrance; even though access to the cave interior was to be maintained by building a tunnel from street level, Archbishop Gray promoted the pilgrimage as demonstrating Catholic attachment to the site in protest at the council's plans ("Archbishop Gray's Letter," 1961, 52). The visual form of the cave entrance, rather than the cave interior, was the important devotional feature for this pilgrimage, as it suggested the presence of the saint in the natural landscape.

Basil Spence's design for the church at Whithorn translated St Ninian's cave into architectural terms: "I believe it is only right and proper that a fitting shrine to St. Ninian should be built with the correct background to the saint," he wrote to Bishop McGee (5 February 1954, SCA, DG/52/2); “that is, a church that reminds pilgrims of St. Ninian's first 
church which was a cave, and that the forecourt should be cobbled with stones brought from that section of the beach in front of St. Ninian's cave." Its rounded shape, angled slot windows to cast hidden light forward, and stone-clad surfaces (including much granite) suggested a cave-like interior. Spence indicated a range of artworks (drawings of 1951, SCA, 74/175/1) - a tapestry reredos, sculptures over the side altars, a standing figure of the saint in front of the entrance screen, a tympanum mosaic or sculpture over the entrance, suggestive of the rich devotional visual culture of a shrine. The style of church as well as its suggested decoration was uncompromisingly modernist in its questioning of received visual, typological and stylistic, conventions, and McGee, who had inherited the design from his predecessor Bishop William Mellon, abandoned it for this reason (letter to clergy, 3 February 1956, SCA, DG/54/3). He approached Goodhart-Rendel because he wanted “a building of a more conservative type and more in harmony with the surroundings," one that was "unmistakably a church" (McGee to Goodhart-Rendel, undated, SCA, DG/54/2). The visual genre of the cave was appropriate for the actual cave as pilgrimage destination, but could not be abstracted into unfamiliar terms and did not need to be transposed to the church as well.

At Carfin, however, the creation of a cave for the Lourdes grotto where none existed before was seen as efficacious in converting the landscape to be inhabited by the sacred, in contrast to the reawakening of a spiritual heritage within the existing landscape at Dunfermline and Whithorn. Each reworking of the grotto made it larger and deeper and more like the cave in the Massabielle hill where the Virgin appeared to Bernadette. This visual replication of the Lourdes cave was common in the late nineteenth and early twentieth centuries. At Notre Dame, Indiana it was the most important of several nineteenth-century replica shrines including the Portiuncula chapel and Holy House of Loreto. The American grotto, like Carfin's, was rebuilt on a larger and more realistic scale at 
the end of the century, and consequently the college became an important regional pilgrimage destination (McDannell, 1995, 155-158). Most influential on Carfin was the replica Lourdes grotto at Oostacker in Belgium, where, he pointed out, prayers to the Virgin at an artificial spring prompted healing miracles (Taylor, 1938, 2; Taylor, 1954, 6). The replica cave had as much spiritual power as the original: imitation did not dilute the authenticity of the shrine but brought its presence to a new site (McDannell, 1995, 160-162; Davies, 2013). Yet it still heightened the presence of the saint at a particular site: in the perception of the pilgrims, and of Taylor, the graces of the Virgin came especially freely and effectively through the Carfin cave, the "Scottish Lourdes." In part, this was because it was seeded through an authentic addition, the incorporation of a stone from the Lourdes grotto into the shrine (Taylor, n.d.).

Unlike the shrines at Notre Dame, the grotto at Carfin was not designed by an architect, but, according to Taylor, was made by the town's coal miners during the strikes of the 1920s. The story of a hundred unemployed male manual laborers working to erect a shrine for the Virgin, though undoubtedly true, gains the force and poetic power of myth in Taylor's words, emphasized by several posed photographs that seem intended to demonstrate the events, perhaps for use as lantern slides in his talks (fig. 17). This narrative associated the digging of the site with the local mining, translating this physical action into an excavation and throwing up of earth for sacred purposes. Later the miners also excavated the lake and sunken garden. The visual appearance of the grotto was acclaimed as the almost miraculous result of spontaneous, divinely-inspired labor; and perhaps that is how it felt for those who participated in its creation. Manual work was thus represented as a primal and spiritual act that could be directed to reveal the sacred. Taylor's use of the local striking labor also co-opted contemporary British political arguments that redundant labor should be put to work on schemes of national infrastructure such as roads (Lloyd George, 1929), 
converting the idea into a national religious plan apparently embraced by the workers themselves.

Yet there is evidence that the grotto and the other rocky cave-like shrines around it the Bethlehem cave, the Portiuncula, the water garden, St Thérèse's promontory - were more carefully orchestrated than Taylor's narratives imply. For example, in 1925 Taylor issued a printed invitation card for an event to parishioners who had helped build the shrine, suggesting his close involvement and motivation of their work (SFX). Careful study of the shrines reveals that they were not roughly built: their rocky appearance belies their processes of construction. Well-built brick and stone buildings were faced with a crazypaving veneer of flat stone pieces intended to look rough and grotto-like (fig. 18), while several structures, including the Bethlehem cave, have façades of cement molded to a rocky form (fig. 19). There was therefore an architectural, design intent: the shrines were made to look rough, visually communicating the idea that they were built by the hands of the faithful as a manifestation of devotion.

The idea of the visual genre provides further ways of understanding this apparent rusticity: it is a designed aesthetic of cave-like spaces, made to look natural; on one hand an architecture of the garden grotto with a much longer history (going back to the Renaissance and beyond), but more immediately with similarities to shrines Taylor knew. Numerous souvenir postcard books in the Carfin archive show how Taylor collected visual imagery associated with sacred landscapes and man-made places. Inevitably these include many images of Lourdes (which by the 1920s had accumulated numerous additional statues around the site), Lisieux (which had an outdoor Way of the Cross), Oostacker, the Holy Land, and the craggy grove where the apparitions occurred at Fatima. Most similar to Carfin is a series of outdoor statues and shrines in a fold-out picture book from the convent at Arenberg near Koblenz in Germany, all made to look rocky like those at Carfin, and 
including a Lourdes grotto, scenes from the life of the Virgin, and a cave of St Francis (fig. 20) (Album von Arenberg, n.d.). The parish priest of the church of St Nicholas at Arenberg, Johann Baptist Krauss, had created a garden of lifelike grotto scenes on a hillside in the mid nineteenth century, attracting a Dominican convent to help transform the site into a pilgrimage destination (Busch, 1983), and it seems no coincidence that the visual and spatial appearances are so similar.

Taylor directed his parishioners into producing spaces of familiar forms, forms in which the sacred was already known to become accessible through their efficacy elsewhere. The parishioners cooperated because Taylor's vision of a sacred landscape was more widely held and understood. Once this landscape was constructed (and despite its very obvious constructed nature), they discovered the sacred in their own creation. Whether found or created, therefore, caves had a particular potency in Scottish Catholic culture, as they did internationally, but perhaps with the special purpose here of enabling the world of heaven to appear in the temporal sphere where the faithful gathered to seek it, through openings in the Scottish landscape.

\section{Open Spaces; Objects; Artistic Excellence}

Other common visual and spatial features of these pilgrimages can be dealt with more briefly. All involved outdoor gatherings, and the crowd assembled in the open air to see Mass or Benediction became an expected feature of twentieth-century Scottish pilgrimages. In part this was due to the extraordinary numbers of pilgrims attending, but it was also desired and designed for. Open-air ceremonies were a vital aspect of the pilgrimage at Lourdes, undoubtedly the principal model. At Whithorn, the outdoor altar was part of the brief for the church, present in Goodhart-Rendel's first design, which positioned the church 
at the top of the sloping garden. Whether or not this was inspired by the similar external altar on the sanctuary wall of Le Corbusier's pilgrimage church at Ronchamp is unknown, but certainly possible, a comparison that suggests a wider international Catholic culture of outdoor gatherings as a type of worship with special resonances. At Carfin, broad, stepped precincts were designed for the ever-increasing crowds to observe and participate in the ceremonies, and allowed theatrical pageants and processions to gain in dramatic potential, closely imitating the events and spaces of the esplanade at Lourdes. The weather was a frequent topic of discussion in the clergy's articulation of pilgrimage, as it must have been for pilgrims: its inclemency increased pilgrims' exertions and thus the merit of the pilgrimage in McGee's discussion of Whithorn, and its miraculous benevolence at Carfin proved to Taylor the approbation of the Little Flower. The heavens became metaphysically as well as literally part of the pilgrim experience.

But for twentieth-century Scottish Catholics, the outdoor gathering had further meanings. It increased the sense of exile and lack of shelter of the kind that the medieval Church had formerly provided. For the Irish, always a large proportion of pilgrims (especially at Carfin and Dunfermline), it evoked the Mass rock and the endurance of worship during periods of persecution; Carfin's shrine of St Patrick even included a "Mass rock" sent from Ireland by a donor - whether a real one or merely a stone for that purpose is not known, but thus it was named. The external setting emphasized the vulnerability of the pilgrim Catholic in a land that was politically and spiritually hostile. Protestant objections to Catholic processions at Carfin were the catalyst for the final stages of legal emancipation and the attainment of equal rights to public religious practice (McGhee, 1965); consciousness of Catholics' status in a non-Catholic society was therefore especially pertinent there. The procession echoed - and sacralized - a broader secular culture of urban processions, including those of the trade unions to which the striking miners subscribed, and must 
especially be seen as a Catholic reaction to Orange Order marches - Protestant, Masonic in style and supporting British union over national identities - which appeared to claim the city as their right (O’Leary, 2012). The outdoor gathering made demonstrations of identity and devotion public, a statement of Catholic solidarity and confidence to outsiders.

On pilgrimages at Dunfermline and Carfin, sacred objects also played a crucial role: the reliquary of St Margaret brought the presence of the saint amongst the faithful (fig. 21) (and was finally acquired by the parish to be housed in the church in 2008). At Carfin, in particular, relics, reliquaries and other sacred objects abounded, housed for admiration and devotion at the "All Saints" chapel and carried in procession. Taylor acquired a huge array of relics, and placed many of them in reliquaries made for him by G. Dupont of Bruges. Some, like Dunfermline's, were medieval in style, as if in anticipation of the future church; others, like that of St Thérèse, were distinctively modern. Relics, including secondary objects such as the Lourdes stone, had a synecdochic function in the Catholic visual culture of pilgrimage: fragments of sacred bodies and places, they nevertheless captured the whole spiritual presence of those bodies and places at the shrine. As with shrine replication, the relic magnified and disseminated saintly presence rather than diluting or fragmenting it, and provided a focus of devotion with the strongest promise of efficacy.

More prominent than the reliquaries, however, was Carfin's processional monstrance, treated like a reliquary for Christ's body in the Eucharistic sacrament (fig. 22). Unusual in style and iconography, with the host placed at the center of a victorious Christ on the cross and some Celtic elements in its design, it was funded with parishioners' donated jewelry, a story Taylor told as if it occurred in the same spontaneous fashion as the miners' labors. He sought these contributions himself: weekly parish notices about the monstrance, presumably announced at Sunday services, were briefly recorded in his log book (“The Carfin Notice Book," 1933-1939), including entries such as "Monstrance: $£ 230$ in 
hand: gold lunette" (28 May 1933) and "Monstrance. Gold watches pl[ease]" (2 July 1933).

Taylor's story of this process, as with that of the miners' excavations, makes clear the constructed nature of the container that houses the sacred presence.

Discussing the monstrance and the elaborate canopy designed to be carried over it, Taylor indicates another pilgrimage genre that seems significant at all three shrines, though more a narrative genre than a visual one: the insistence on the important artistic status of the shrine according to external canons of taste. The canopy was designed by Dupont but made by his assistant, a 19-year-old apprentice: Dupont "saw immediately that God had sent him a genius," reported Taylor ([Taylor], n.d. [c. 1935]); it was made in "only eight months," though it had taken twelve to design and should have taken years; "The whole is a masterpiece of delicate open work carving." Most of the shrine's statues, meanwhile, were of Carrara marble, and that of St Francis (by Dupont's cousin M. A. Dupont, a noted sculptor), was, he said, "pronounced by experts to be, from an artistic point of view, the masterpiece of the Grotto;" though he also called the statue of Our Lady Star of the Sea a "masterpiece, entirely original" (Taylor, n.d.; Taylor 1938, 20). Such language can be found in French devotional literature present at Carfin, echoing the hyperbolic guidebook language of art galleries or department stores: a booklet describing a room of relics of St Thérèse at Lisieux, for example, draws attention to a painting, "A striking portrait of the Blessed One, masterpiece of the painter Roybet," whose qualities include a penetrating gaze that follows the viewer (La Salle des Reliques, n.d.). Why such insistence on a secular artistic quality should have been so prominent is difficult to interpret; perhaps, as artists of high caliber were thought most able to translate underlying reality into visual representation, attributing artistic quality to an object claimed a greater transparency to the sacred presence within it (see also Morgan, 2009, 54-57, discussing the statue of Our Lady of Fatima). 
This desire for artistic quality also applied to architecture. Fairlie was an obvious choice as an architect of Roman Catholic churches across Scotland in the period (though Taylor alluded to his broader renown as "the distinguished Edinburgh architect") (Taylor, 1938, 12). Yet the choices of Anderson at Dunfermline, Spence and, to a lesser extent, Goodhart-Rendel at Whithorn, suggest an anxiety to commission architects of repute more than religion or familiarity. Anderson had built very little for Catholic projects before Dunfermline, and was better known as an architect of Episcopalian churches; his connection was the Marquess of Bute, since Anderson was the architect of his house, Mount Stuart ("[Sir] Robert Rowand Anderson," n.d.). The later Marquess was also likely to have been the connection to the non-Catholic Spence, just then at the height of his national fame after winning the Anglican Coventry Cathedral competition. While the move to Goodhart-Rendel represented a preference for both a Catholic and a conservative architect, it was also a choice of a well-regarded London designer, a former president of the Royal Institute of British Architects (Powers, 1987). When Catholic clergy chose non-Catholics for cathedral projects, such as at Liverpool and Clifton in the post-war period, it suggested a desire to demonstrate to the secular world a level of status achieved by the Catholic community, conveyed through the medium of taste (Proctor, 2014, 52, 123-125). A similar principle likely operated in these pilgrimage sites. In Galloway, McGee argued in favor of building a church despite the cost "not simply as a matter of supplying the needs of the Catholic community of Whithorn but as one involving the prestige of the Catholic Church in this Diocese and, indeed, in Scotland" (letter to clergy, 3 February 1956, SCA, DG/54/3). The pilgrimage church, like the cathedral, was deemed too special to be given to an ordinary church architect with whom a diocese was already familiar; it had to be the work of an architect with a reputation beyond Catholicism and the humdrum world of the jobbing diocesan architect, deemed thereby to 
have a higher artistic ability, and therefore able to create a transcendent space in which the sacred could be felt.

\section{Conclusion: The Religious Politics of Pilgrimage}

The work of art and the relic are perhaps less consistent genres at these Scottish sites than the other, more important features of pilgrimage: the outdoor gathering (expected even in Taylor's vast church project); the cave; and the medievalizing dream church, often juxtaposed with the medieval ruin. These features are consistent across the three sites, although the pilgrimages were of two distinct characters. The pre-Reformation revivals at Dunfermline and Whithorn and the international devotional campaigns at Carfin aimed to remake Scotland as a new Catholic country. Part of the work of achieving this broad and ambitious aim was to return the old saints to their places in the landscape, and to construct new places for the saints of the universal Church to inhabit and communicate with the faithful. The production of familiar visual and spatial forms, with broadly agreed religious efficacy, resonating also with contemporary secular culture, quelled any appearance of tensions or anxieties over these representations within the Catholic community. At the same time these pilgrimages and their material culture proposed a particular view of Scotland as a nation bound to Rome through ancient ties, and indeed to contemporary Catholic Europe through transnational mobilities and allegiances. Together the clergy and the laity constructed this new religious landscape, and activated it through participation in rituals of pilgrimage. 


\section{References}

Album von Arenberg. n.d. n.pub. (SFX)

Anderson, Benedict. 1991. Imagined Communities: Reflections on the Origin and Spread of Nationalism. London: Verso.

“Annual Pilgrimage to Dunfermline." 1961. In The St Andrew Annual: The Catholic Church in Scotland, edited by David McRoberts, 66-67. Glasgow: John S. Burns \& Sons.

ARCAG (Archives of the Roman Catholic Archdiocese of Glasgow), unpublished archival records.

“Archbishop Gray's Letter on the Cave of St Margaret at Dunfermline.” 1961. In The St Andrew Annual: The Catholic Church in Scotland, edited by David McRoberts, 52. Glasgow: John S. Burns \& Sons.

Basciano, Jessica. 2018. "Sisterly Love in Lisieux: Building the Basilica of Sainte-Thérèse." In Modern Architecture and Religious Communities, 1850-1970: Building the Kingdom, edited by Ayla Lepine and Kate Jordan, 15-29. Abingdon: Routledge.

Bowman, Marion. 2015. “Railways, Rivalry and the Revival of Pilgrimage in Glastonbury, 1895 and 1897." In Religion, Culture, Society 2: Yearbook of the MTA-SZTE Research Group for the Study of Religious Culture, edited by Gábor Barna and Orsolya Gyöngyössy, 168-190. Szeged: MTA-SZTE Research Group for the Study of Religious Culture.

Bowman, Marion and Ülo Valk. 2012. “Introduction: Vernacular Religion, Generic Expressions and the Dynamics of Belief." In Vernacular Religion in Everyday Life: Expressions of Belief, edited by Marion Bowman and Ülo Valk, 1-19. Sheffield: Equinox, 2012. 
Burnett, Ray. 1998. “The Long Nineteenth Century:' Scotland’s Catholic Gaidhealtachd.” In Out of the Ghetto? The Catholic Community in Modern Scotland, edited by Raymond Boyle and Peter Lynch, 163-192. Edinburgh: John Donald.

Busch, Silvia Maria. 1983. “Die 'Heiligen Orte’ zu Arenberg. Eine Wallfahrtsanlage der katholischen Spätromantik im Rheinland und Johann Baptist Kraus’ Idee der Gralsarchitektur." Accessed 16 October 2016. http://www.arenberg-info.de/htm/HOrte.htm

"Cardinal Bourne in Scotland". 1924. Tablet. 26 July.

Catholic Directory for the Clergy and Laity of Scotland; St Margaret's, Dunfermline. 1946. n.pub.

Coleman, Simon. 2004. “Pilgrimage to 'England's Nazareth': Landscapes of Myth and Memory at Walsingham." In Intersecting Journeys: The Anthropology of Pilgrimage and Tourism, edited by Ellen Badone and Sharon R. Roseman, 52-67. Urbana and Chicago: University of Illinois Press.

Coleman, Simon. 2009. “Mary on the Margins? The Modulation of Marian Imagery in Place, Memory, and Performance." In Moved by Mary: The Power of Pilgrimage in the Modern World, edited by Anna-Karina Hermkens, Willy Jansen and Catrien Notermans, 1732. Farnham: Ashgate.

CYMS (Catholic Young Men's Society). 1936. Pilgrimage to Whithorn in Honour of St Ninian on Sunday, 28th June 1936. Official Programme. n.pub. (SCA, DG/84/3).

Davies, Paul. 2013. “Likeness in Italian Renaissance Pilgrimage Architecture.” In Architecture and Pilgrimage, 1000-1500: Southern Europe and Beyond, edited by Paul Davies, Deborah Howard and Wendy Pullan, 187-211. Farnham: Ashgate.

“Dunfermline Pilgrimage: Where Scotland's Personality Comes From." 1953. The Mercat Cross: Scottish Catholic Monthly, June. 
Eade, John and Michael J. Sallnow. 1991. "Introduction." In Contesting the Sacred: The Anthropology of Christian Pilgrimage, edited by John Eade and Michael J. Sallnow, 1-29. London: Routledge.

Harris, Alana. 2015. “Astonishing Scenes at the Scottish Lourdes: Masculinity, the Miraculous, and Sectarian Strife at Carfin, 1922-1945." The Innes Review. 66 (1): 102129. doi: 10.3366/inr.2015.0086.

Hermkens, Anna-Karina, Willy Jansen and Catrien Notermans. 2009. “Introduction: The Power of Marian Pilgrimage." In Moved by Mary: The Power of Pilgrimage in the Modern World, edited by Anna-Karina Hermkens, Willy Jansen and Catrien Notermans, 1-13. Farnham: Ashgate.

Humphrey, Caroline and James Laidlaw. 1994. The Archetypal Actions of Ritual: A Theory of Ritual Illustrated by the Jain Rite of Worship. Oxford: Clarendon Press.

Kerr, Cecil. 1930. St. Margaret, Queen of Scotland. London: Catholic Truth Society. La Salle des Reliques au Carmel de Lisieux. n.d. n.pub. (SFX).

“Little Flower is Honoured at Carfin Shrine." 1947. Catholic Times. 3 October.

Lloyd George, David. 1929. We Can Conquer Unemployment. London: Cassell and Company. Maguire, J. 1936. “Record of Events. Dunfermline”. n.pub. (unpublished). (SCA, GD/40/1). McCaffrey, John. "Politics and the Catholic Community Since 1978". In Modern Scottish Catholicism, 1878-1978, edited by David McRoberts, 140-155. Glasgow: Scottish Catholic Historical Association.

McDannell, Colleen. 1995. Material Christianity: Religion and Popular Culture in America. New Haven: Yale University Press.

McGhee, Susan. 1965. "Carfin and the Roman Catholic Relief Act of 1926." Innes Review. 16 (1), 56-78. doi: 10.3366/inr.1965.16.1.56 
McKerlie, E. Marianne H. 1936. “Saint Ninian.” In CYMS (Catholic Young Men's Society), Pilgrimage to Whithorn in Honour of St Ninian on Sunday, 28th June 1936. Official Programme, 3-7. n.pub. (SCA, DG/84/3).

Mercer, Giles. 2012. “The 1895 Glastonbury Pilgrimage”. Downside Review. 458: 79-107. Mesaritou, Evgenia. 2012. "Say a Little Hallo to Padre Pio: Production and Consumption of Space in the Construction of the Sacred at the Shrine of Santa Maria delle Grazie." In Ordinary Lives and Grand Schemes: An Anthropology of Everyday Religion, edited by Samuli Schielke and Liza Debevec, 98-112. New York: Berghahn Books.

Mesaritou, Evgenia. 2015. "'He is Among Us, Get it into Your Head, He is Alive and Always Here': Saintly Presence at the Pilgrimage Centre of Padre Pio and the Importance of ‘Being There'”. Culture and Religion. 16 (1): 87-109. doi: $10.1080 / 14755610.2015 .1019896$.

Morgan, David. 2005. The Sacred Gaze: Religious Visual Culture in Theory and Practice. Berkeley: University of California Press.

Morgan, David. 2009. “Aura and the Inversion of Marian Pilgrimage: Fatima and Her Statues." In Moved by Mary: The Power of Pilgrimage in the Modern World, edited by Anna-Karina Hermkens, Willy Jansen and Catrien Notermans, 49-65. Farnham: Ashgate.

Nuttgens, Patrick. 1959. Reginald Fairlie, 1883-1952: A Scottish Architect. Edinburgh: Oliver and Boyd.

O'Leary, Paul. 2012. Claiming the Streets: Processions and Urban Culture in South Wales c. 18301880. Cardiff: University of Wales Press.

Panchenko, Alexander. 2012. "How to Make a Shrine with Your Own Hands: Local Holy Places and Vernacular Religion in Russia." In Vernacular Religion, edited by Marion Bowman and Ülo Valk, 42-62. Sheffield: Equinox, 2012. 
Pócs, Éva. “’We, Too, Have Seen a Great Miracle’: Conversations and Narratives on the Supernatural Among Hungarian-Speaking Catholics in a Romanian Village." In Vernacular Religion, edited by Marion Bowman and Ülo Valk, 246-280. Sheffield: Equinox, 2012.

Powers, Alan, ed. 1987. H. S. Goodhart-Rendel, 1887-1959. London: Architectural Association. Proctor, Robert. 2014. Building the Modern Church: Roman Catholic Church Architecture in Britain, 1955 to 1975. Aldershot: Ashgate/Routledge.

Roberts, David. n.d. The Pilgrimage to Whithorn. Glasgow: n.pub.

Ross, Anthony. 1978. "The Development of the Scottish Catholic Community, 1878-1978”. In Modern Scottish Catholicism, 1878-1978, edited by David McRoberts, 30-55. Glasgow: Scottish Catholic Historical Association.

SCA (Scottish Catholic Archives), Edinburgh, unpublished archival records.

SFX (Saint Francis Xavier parish archives), Carfin, unpublished and uncatalogued archival records.

“(Sir) Robert Rowand Anderson." n.d. Dictionary of Scottish Architects. Accessed 16 October 2016. http://www.scottisharchitects.org.uk/architect_full.php?id=200041

Solemn Opening. New Church of St Francis Xavier, Carfin. Sunday, 9th December, 1973. 1973. n.pub.

St Margaret's, Dunfermline. 1946. n.pub.

Taylor, Thomas N. 1933. “Carfin Grotto: Lantern Lecture Script”. Unpublished. (SFX).

[Taylor, Thomas N.] n.d. (c.1935). “All Saints Chapel, Carfin”. Unpublished. (SFX).

Taylor, T. N. 1938. The Carfin Grotto: The First Fifteen Years. London: Catholic Truth Society.

[Taylor, Thomas N.]. 1947. Carfin Grotto Shrines: Silver Jubilee Edition, 1922-1947. n.pub. (SFX).

Taylor, Thomas N. n.d. (c.1950). The Carfin Grotto. n.pub. (SFX). 
Taylor, Thomas N. Canon. 1954. Carfin Grotto 1954: Supplement to "The First Thirty Years 1922-1952". n.pub. (SFX).

[Taylor, Thomas N.] 1962. St Francis Xavier's Parish, Carfin, 1862-1962. n.pub. (SFX).

“The Carfin Notice Book. Circumcision 1933 to Passion Sun. 1939”. 1933-1939. Unpublished. (SFX).

Turner, Edith. 2009. “Legitimization or Suppression? The Effect of Mary's Appearances at Knock, Ireland." In Moved by Mary: The Power of Pilgrimage in the Modern World, edited by Anna-Karina Hermkens, Willy Jansen and Catrien Notermans, 201-214. Farnham: Ashgate.

Turner, Victor and Edith Turner. (1978) 2011. Image and Pilgrimage in Christian Culture. New York: Columbia University Press.

UEA (University of Edinburgh Archives), Edinburgh, unpublished archival records.

Watters, Diane M. 2016. St Peter's, Cardross: Birth, Death and Renewal. Edinburgh: Historic Environment Scotland. 